\title{
Characteristics and chemical compositions of propolis from Ethiopia
}

\author{
Ahmed I Rushdi ${ }^{1,2,3^{*}}$, Nuru Adgaba ${ }^{4}$, Noofal I M Bayaqoob ${ }^{4}$, Ahmed Al-Khazim ${ }^{4}$, Bernd R T Simoneit ${ }^{1,5}$, \\ Aarif H El-Mubarak ${ }^{1}$ and Khalid F Al-Mutlaq ${ }^{1}$
}

\begin{abstract}
Introduction: Propolis is a sticky material mixed by honeybees to utilize it in protecting their hives from infection by bacteria and fungi. The therapeutic properties of propolis are due to its chemical composition with bio-active compounds; therefore, researchers are interested in studying its chemical constituents and biological properties. The main objective of this study is to determine the chemical compositions, characteristics and relative concentrations of organic compounds in the extractable organic matter of propolis samples collected from four different areas in Ethiopia.
\end{abstract}

Results: The propolis samples were extracted with a mixture of dichloromethane and methanol and analyzed by gas chromatography-mass spectrometry (GC-MS).The results showed that the total extract yields ranged from $27.2 \%$ to $64.2 \%$ ( $46.7 \pm 19.1 \%)$. The major compounds were triterpenoids $(85.5 \pm 15.0 \%$ of the total extracts, mainly $\alpha$-, $\beta$-amyrins and amyryl acetates), $n$-alkanes (5.8 $\pm 7.5 \%), n$-alkenes $(6.2 \pm 7.0 \%$,$) , methyl n$-alkanoates $(0.4 \pm 0.2 \%)$, and long chain wax esters (0.3 to $2.1 \%)$.

Conclusion: The chemical compositions of these propolis samples indicate that they are potential sources of natural bio-active compounds for biological and pharmacological applications.

Keywords: Propolis; Ethiopia; Triterpenoids; GC-MS

\section{Introduction}

Honeybees collect resinous/waxy substances from exudates of plants to make a sticky material known as propolis (Ghisalberti 1979; Parolia et al. 2010). They utilize propolis to seal cracks in hives, encapsulate invader carcasses and protect their hives from infection by bacteria and fungi (Banskota et al. 2001; Simone-Finstrom \& Spivak 2010). In ancient times, Egyptians, Greeks and Romans all used propolis as a remedy against some diseases (Sforcin \& Bankova 2011). The therapeutic properties of propolis are due to its chemical composition with bioactive compounds; therefore, researchers are interested in studying its chemical constituents and biological properties (Sforcin \& Bankova 2011; Bankova 2005; Castaldo \& Capasso 2002; Sforcin 2007). The diverse chemical

\footnotetext{
* Correspondence: arushdi@ksu.edu.sa

${ }^{1}$ Chair of Green Energy Research, College of Food and Agriculture Sciences, King Saud University, P. O. Box 2460, Riyadh 11451, Saudi Arabia ${ }^{2}$ College of Earth, Oceanic and Atmospheric Sciences, Oregon State University, Corvallis, Oregon 97331, USA

Full list of author information is available at the end of the article
}

compositions and biological activities of propolis are attributed to geographical settings, plant sources and collecting season (Sforcin \& Bankova 2011). Flavonoids, aromatic acids, diterpenoid acids, triterpenoids, and phenolic compounds are the major components of propolis (Bankova et al. 2000; Chen et al. 2008; Cursta-Rubio et al. 2007; Daugsch et al. 2008; Kumazawa et al. 2008; Markham et al. 1996; Popova et al. 2010). Some of these compounds are responsible for its biological activities (Bankova et al. 2000; Barros et al. 2007; Bassani-Silva et al. 2007; Bufalo et al. 2009; Cvek et al. 2007; Orsatti et al. 2010a; Orsatti et al. 2010b; Orsi et al. 2005; Zamami et al. 2007). There are three possible sources for the organic compounds of propolis: plants, secreted substances from honeybee metabolism, and materials that are introduced during propolis formation (Marcucci 1995). Propolis is typically composed of 50\% resin and vegetable balsam, 30\% wax, 10\% essential and aromatic oils, $5 \%$ pollen and $5 \%$ other substances (Cirasino et al. 1987; Monti et al. 1983). Most of the studies on propolis composition and pharmacological 

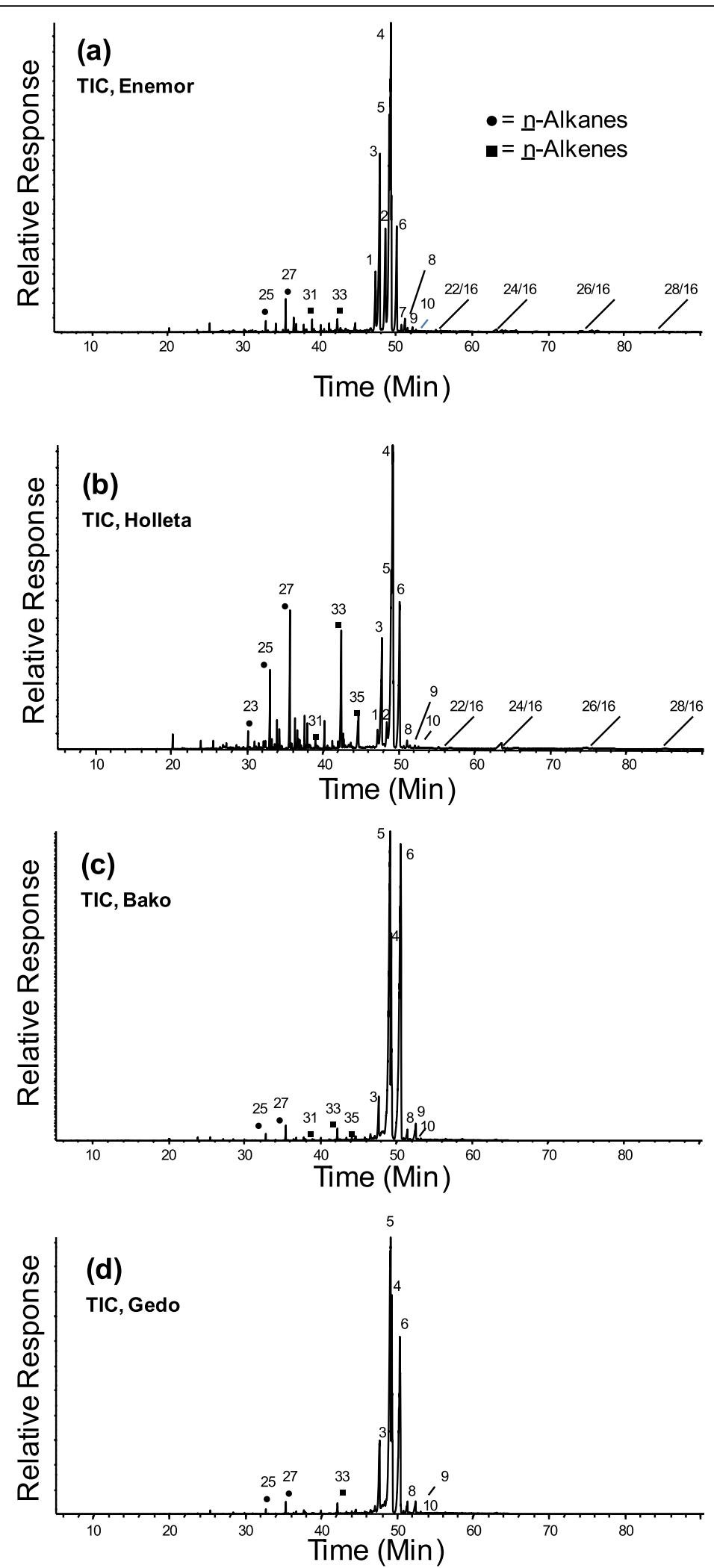

Figure 1 (See legend on next page.) 
(See figure on previous page.)

Figure 1 Total ion current (TIC) traces showing the major organic tracers in propolis samples collected from. (a) Enemor (Gurghe), (b) Holleta, (c) Bako, and (d) Gedo localities in Ethiopia ( 1 = $\beta$-amyrone, 2 =a-amyrone, $3=\beta$-amyrin, 4 = $a$-amyrin, $5=\beta$-amyryl acetate, $6=\alpha$-amyryl acetate, 7 = lup-20(29)-en-3-one, 8 = lupeol, $9=\beta$-lupeyl acetate, 10 = a-lupeyl acetate, 22/16, 24/16, 26/16 and 28/16 are docosyl hexadecanoate, tetracosyl hexadecanoate, hexacosyl hexadecanoate and octacosyl hexadecanoate, respectively; numbers above the symbols indicate the carbon number).

effects have been performed on samples from Europe and Latin America (e.g. (Bankova et al. 2000; Daugsch et al. 2008; Barros et al. 2007; Monti et al. 1983)), whereas few have reported on propolis from north Africa (El-Hady \& Hegazi 2002; Hegazi \& El-Hady 2002) with none from Ethiopia. Ethiopia is located in north-eastern Africa with varied climatic and physiographic conditions that endowed the country with more than 7,000 species of flowering plants (Edwards 1976). They are considered as a potential for producing huge volume of propolis with high probabilities for various biologically active substances. However, many beekeepers in the country focus only on honey production.

Therefore, the main objective of this study is to determine the chemical compositions, characteristics and relative concentrations of organic compounds in the extractable organic matter of propolis samples collected from four different areas in Ethiopia.

\section{Results}

The main features of the GC-MS data and the major extractable organic compound concentrations for the propolis samples are shown in Figure 1 and listed in Table 1, respectively. They included titerpenoids, $n$-alkanes, $\mathrm{n}$-alkenes, $n$-alkanoic acids, methyl $n$-alkanoates, and long chain wax esters (Table 1). The major triterpenoids were $\alpha$ - and $\beta$-amyrins $(0.0-83.8 \%$ of total extract), and $\alpha$ - and $\beta$-amyryl acetates $(0.0-53.8 \%$ of total extract) (Figures $1,2 \mathrm{~d}$,e and Table 1). For $n$-alkanes the major compounds were pentacosane $(0.20-4.50 \%$ of total extract), heptacosane (0.44-7.56\% of total extract), nonacosane $(0.08-1.27 \%$ of total extract), and hentriacontane (0.06-1.16\% of total extract) (Table 1 , Figure 2a). Tritriacontene (0.53-9.06\% of total extract) was the major compound for the n-alkene group (Table 1 and Figure 2b), whereas methyl hexanoate (0.09-0.30\% of total extract) was the major compound for the methyl $n$-alkanoates (Table 1 and Figure 2c). The major compound for wax esters was found to be tetracosyl hexadecanoate $(0.19-1.75 \%$; Table 1 and Figure 2f).

\section{Discussion}

The chemical compositions of propolis samples obviously vary between different samples (Popova et al. 2010; ElHady \& Hegazi 2002; Hegazi \& El-Hady 2002; Edwards 1976; Popova et al. 2011; Trusheva et al. 2003). Recent studies have shown that diterpenoids were the major compounds in propolis samples from Greece and Sicily (Popova et al. 2010; Trusheva et al. 2003; Popova et al. 2009). The major components of Greek propolis consist of communic, cupressic, isocupressic acids and totarol (Popova et al. 2010), indicating a potential origin from conifer (e.g. cedar) resin (Cox et al. 2007). Triterpenoids including $\beta$-amyrin, $\beta$-amyrone, lupeol, and lupenone, and polyprenyl benzophenones such as 7epi-nemorosone, 7-epi-clusianone, xanthochymol, and gambogenone have been detected in propolis samples from the Brazilian Amazon (de Castro Ishida et al. 2011). Propolis samples from Egypt contained caffeate esters, triterpenoids with major diterpenoids, but no aromatic acids and flavonoids (El-Hady \& Hegazi 2002; Hegazi \& El-Hady 2002). The results show that these propolis extracts include primarily lipid compounds from terrestrial plant sources as reported before (Bankova et al. 2000; CurstaRubio et al. 2007; Ugur et al. 2011; Campo Fernandez et al. 2008; Lotti et al. 2010; Melliou \& Chinou 2004; Salatino et al. 2005). Phenols (e.g. flavonoids) or other antioxidants were not detected.

\section{Triterpenoids}

Triterpenoids have been reported to occur in diverse plant species as resin or gum constituents (Cursta-Rubio et al. 2007; de Castro Ishida et al. 2011). They are rarely found in fungi and animals (Lutta et al. 2008). Therefore, the major source of triterpenoids is terrestrial vegetation (Hernández-Vázquez et al. 2010; Manguro et al. 2009; Moreau et al. 2009; Ramadan et al. 2009). They are found in plant leaves (Ramadan et al. 2009; van Maarseveen \& Jetter 2009; Silva et al. 2009), bark (Hernández-Vázquez et al. 2010; Rosas-Acevedo et al. 2011; Feng et al. 2010; Vouffo et al. 2010), resins (Hernández-Vázquez et al. 2010; Manguro et al. 2009; Wang et al. 2011), and oils (Moreau et al. 2009; Akihisa et al. 2010; BakowskaBarczak et al. 2009; Wesolowska et al. 2011). Their concentrations vary and depend on the plant species. For example, $\alpha$ - and $\beta$-amyrin are found in Protium sp. Byrosonima fagifolia and Byrosonima crassifolia (Hernández-Vázquez et al. 2010) and only $\alpha$-amyrin is present in Cassia obtusifolia (Sob et al. 2010).

The main compounds in these propolis samples were triterpenoids. The relative concentrations of these substances ranged from $64.0 \%$ to $97.6 \%$ with a mean value of $85.5 \pm 15.0 \%$. They were mainly $\alpha$ - and $\beta$-amyrones, 
Table 1 The relative concentrations (\%), and organic parameters of the various lipid compound groups of propolis samples from different regions of Ethiopia

\begin{tabular}{|c|c|c|c|c|c|c|c|c|}
\hline & & & Enemore & Holleta & Bako & Gedo & Average & SD \\
\hline Yield (\%) & & & 27.2 & 33.4 & 62.0 & 64.2 & 46.7 & 19.1 \\
\hline Compound & Composition & M.W. & & & & & & \\
\hline \multicolumn{9}{|l|}{ Triterpenoids } \\
\hline$\beta$-Amyrone & $\mathrm{C}_{30} \mathrm{H}_{48} \mathrm{O}$ & 424 & 0.08 & 0.01 & 0.36 & 1.16 & & \\
\hline a-Amyrone & $\mathrm{C}_{30} \mathrm{H}_{48} \mathrm{O}$ & 424 & 0.19 & 0.01 & 0.00 & 1.88 & & \\
\hline$\beta$-Amyrin & $\mathrm{C}_{30} \mathrm{H}_{50} \mathrm{O}$ & 426 & 0.29 & 0.12 & 3.29 & 0.00 & & \\
\hline a-Amyrin & $\mathrm{C}_{30} \mathrm{H}_{50} \mathrm{O}$ & 426 & 83.79 & 63.11 & 0.00 & 3.16 & & \\
\hline$\beta$-Amyryl acetate & $\mathrm{C}_{32} \mathrm{H}_{52} \mathrm{O}_{2}$ & 468 & 0.15 & 0.19 & 44.88 & 53.79 & & \\
\hline a-Amyryl acetate & $\mathrm{C}_{32} \mathrm{H}_{52} \mathrm{O}_{2}$ & 468 & 0.00 & 0.00 & 46.72 & 29.72 & & \\
\hline Lupeol & $\mathrm{C}_{30} \mathrm{H}_{50} \mathrm{O}$ & 426 & 1.81 & 0.24 & 2.29 & 1.84 & & \\
\hline Moretenol & $\mathrm{C}_{32} \mathrm{H}_{52} \mathrm{O}_{2}$ & 426 & 0.46 & 0.19 & 0.05 & 2.04 & & \\
\hline Moretenyl acetate & $\mathrm{C}_{32} \mathrm{H}_{52} \mathrm{O}_{2}$ & 468 & 0.15 & 0.09 & 0.00 & 0.09 & & \\
\hline Total & & & 86.91 & 63.96 & 97.60 & 93.67 & 85.53 & 15.04 \\
\hline \multicolumn{9}{|l|}{ n-Alkanes } \\
\hline Heneicosane & $\mathrm{C}_{21} \mathrm{H}_{44}$ & 296 & 0.00 & 0.00 & 0.00 & 0.01 & & \\
\hline Docosane & $\mathrm{C}_{22} \mathrm{H}_{46}$ & 310 & 0.00 & 0.00 & 0.00 & 0.00 & & \\
\hline Tricosane & $\mathrm{C}_{23} \mathrm{H}_{48}$ & 324 & 0.14 & 1.02 & 0.03 & 0.05 & & \\
\hline Tetracosane & $\mathrm{C}_{24} \mathrm{H}_{50}$ & 338 & 0.01 & 0.25 & 0.01 & 0.02 & & \\
\hline Pentacosane & $\mathrm{C}_{25} \mathrm{H}_{52}$ & 352 & 0.58 & 4.50 & 0.20 & 0.37 & & \\
\hline Hexacosane & $\mathrm{C}_{26} \mathrm{H}_{54}$ & 366 & 0.10 & 0.58 & 0.03 & 0.04 & & \\
\hline Heptacosane & $\mathrm{C}_{27} \mathrm{H}_{56}$ & 380 & 1.88 & 7.56 & 0.44 & 0.93 & & \\
\hline Octacosane & $\mathrm{C}_{28} \mathrm{H}_{58}$ & 394 & 0.12 & 0.36 & 0.02 & 0.04 & & \\
\hline Nonacosane & $\mathrm{C}_{29} \mathrm{H}_{60}$ & 408 & 0.38 & 1.27 & 0.08 & 0.25 & & \\
\hline Triacontane & $\mathrm{C}_{30} \mathrm{H}_{62}$ & 422 & 0.02 & 0.18 & 0.00 & 0.03 & & \\
\hline Hentriacontane & $\mathrm{C}_{31} \mathrm{H}_{64}$ & 436 & 0.32 & 1.16 & 0.06 & 0.21 & & \\
\hline Total & & & 3.54 & 16.89 & 0.87 & 1.94 & 5.82 & 7.48 \\
\hline $\mathrm{CPI}(\mathrm{o} / \mathrm{e})^{\mathrm{a}}$ & & & 13.56 & 10.95 & 12.26 & 14.25 & 12.75 & 1.46 \\
\hline \multicolumn{9}{|l|}{ n-Alkenes } \\
\hline Pentacosene & $\mathrm{C}_{25} \mathrm{H}_{50}$ & 350 & & & & 0.009 & & \\
\hline Hexacosene & $\mathrm{C}_{26} \mathrm{H}_{52}$ & 364 & & & & 0.012 & & \\
\hline Heptacosene & $\mathrm{C}_{27} \mathrm{H}_{54}$ & 378 & & & & 0.014 & & \\
\hline Octacosene & $\mathrm{C}_{28} \mathrm{H}_{56}$ & 392 & 1.68 & 1.40 & 0.06 & 0.093 & & \\
\hline Nonacosene & $\mathrm{C}_{29} \mathrm{H}_{58}$ & 406 & 0.27 & 0.17 & 0.02 & 0.033 & & \\
\hline Triacontene & $\mathrm{C}_{30} \mathrm{H}_{60}$ & 420 & 1.31 & 0.83 & 0.04 & 0.042 & & \\
\hline Hentriacontene & $\mathrm{C}_{31} \mathrm{H}_{62}$ & 434 & 0.05 & 1.27 & 0.01 & 0.037 & & \\
\hline Dotriacontene & $\mathrm{C}_{32} \mathrm{H}_{64}$ & 448 & 0.89 & 0.48 & 0.04 & 0.047 & & \\
\hline Tritriacontene & $\mathrm{C}_{33} \mathrm{H}_{66}$ & 462 & 8.11 & 9.06 & 0.53 & 0.912 & & \\
\hline Tetratriacontene & $\mathrm{C}_{34} \mathrm{H}_{68}$ & 476 & 0.20 & 0.13 & 0.00 & 0.033 & & \\
\hline Pentatriacontene & $\mathrm{C}_{35} \mathrm{H}_{70}$ & 490 & 0.86 & 2.54 & 0.14 & 0.284 & & \\
\hline Total & & & 6.61 & 15.88 & 0.85 & 1.515 & 6.23 & 6.96 \\
\hline $\mathrm{CPI}(\mathrm{O} / \mathrm{e})^{\mathrm{b}}$ & & & 2.49 & 5.39 & 6.10 & 7.24 & 5.30 & 2.02 \\
\hline \multicolumn{9}{|c|}{ Methyl n-Alkanoates } \\
\hline Methyl dodenoate & $\mathrm{C}_{13} \mathrm{H}_{26} \mathrm{O}_{2}$ & 214 & 0.000 & 0.000 & 0.000 & 0.001 & & \\
\hline
\end{tabular}


Table 1 The relative concentrations (\%), and organic parameters of the various lipid compound groups of propolis samples from different regions of Ethiopia (Continued)

\begin{tabular}{|c|c|c|c|c|c|c|c|c|}
\hline Methyl tridecanoate & $\mathrm{C}_{14} \mathrm{H}_{28} \mathrm{O}_{2}$ & 228 & 0.000 & 0.000 & 0.000 & 0.000 & & \\
\hline Methyl tetradecanoate & $\mathrm{C}_{15} \mathrm{H}_{30} \mathrm{O}_{2}$ & 242 & 0.004 & 0.004 & 0.001 & 0.001 & & \\
\hline Methyl pentadecanoate & $\mathrm{C}_{16} \mathrm{H}_{32} \mathrm{O}_{2}$ & 256 & 0.003 & 0.001 & 0.001 & 0.001 & & \\
\hline Methyl hexadecenoate & $\mathrm{C}_{17} \mathrm{H}_{32} \mathrm{O}_{2}$ & 286 & 0.006 & 0.000 & 0.000 & 0.000 & & \\
\hline Methyl hexadecanoate & $\mathrm{C}_{17} \mathrm{H}_{34} \mathrm{O}_{2}$ & 270 & 0.304 & 0.222 & 0.093 & 0.123 & & \\
\hline Methyl heptadecenoate & $\mathrm{C}_{18} \mathrm{H}_{34} \mathrm{O}_{2}$ & 282 & 0.001 & 0.000 & 0.000 & 0.001 & & \\
\hline Methyl octadecenoate & $\mathrm{C}_{19} \mathrm{H}_{36} \mathrm{O}_{2}$ & 296 & 0.006 & 0.013 & 0.008 & 0.011 & & \\
\hline Methyl octadecanoate & $\mathrm{C}_{19} \mathrm{H}_{38} \mathrm{O}_{2}$ & 298 & 0.029 & 0.021 & 0.008 & 0.012 & & \\
\hline Methyl nonadecanoate & $\mathrm{C}_{20} \mathrm{H}_{40} \mathrm{O}_{2}$ & 312 & 0.001 & 0.000 & 0.000 & 0.000 & & \\
\hline Methyl eicosanoate & $\mathrm{C}_{21} \mathrm{H}_{42} \mathrm{O}_{2}$ & 326 & 0.010 & 0.007 & 0.004 & 0.007 & & \\
\hline Methyl heneicosanoate & $\mathrm{C}_{22} \mathrm{H}_{44} \mathrm{O}_{2}$ & 340 & 0.001 & 0.000 & 0.000 & 0.001 & & \\
\hline Methyl docosanoate & $\mathrm{C}_{23} \mathrm{H}_{46} \mathrm{O}_{2}$ & 354 & 0.018 & 0.010 & 0.004 & 0.005 & & \\
\hline Methyl tricosanoate & $\mathrm{C}_{24} \mathrm{H}_{48} \mathrm{O}_{2}$ & 368 & 0.031 & 0.004 & 0.002 & 0.002 & & \\
\hline Methyl tetracosanoate & $\mathrm{C}_{25} \mathrm{H}_{50} \mathrm{O}_{2}$ & 382 & 0.199 & 0.160 & 0.045 & 0.065 & & \\
\hline Methyl pentacosanoate & $\mathrm{C}_{26} \mathrm{H}_{52} \mathrm{O}_{2}$ & 396 & 0.001 & 0.000 & 0.000 & 0.001 & & \\
\hline Methyl hexacosanoate & $\mathrm{C}_{27} \mathrm{H}_{54} \mathrm{O}_{2}$ & 410 & 0.058 & 0.048 & 0.013 & 0.017 & & \\
\hline Methyl heptacosanoate & $\mathrm{C}_{28} \mathrm{H}_{56} \mathrm{O}_{2}$ & 424 & 0.000 & 0.000 & 0.000 & 0.000 & & \\
\hline Methyl octacosanoate & $\mathrm{C}_{29} \mathrm{H}_{58} \mathrm{O}_{2}$ & 438 & 0.035 & 0.029 & 0.009 & 0.012 & & \\
\hline Total & & & 0.709 & 0.521 & 0.189 & 0.260 & 0.419 & 0.239 \\
\hline $\mathrm{CPI}(\mathrm{o} / \mathrm{e} \text { as esters })^{c}$ & & & 16.92 & 87.04 & 45.63 & 0.28 & 37.47 & 37.99 \\
\hline \multicolumn{9}{|l|}{ Wax esters } \\
\hline Docosyl hexadecanoate & $\mathrm{C}_{38} \mathrm{H}_{76} \mathrm{O}_{2}$ & 564 & 0.15 & 0.17 & 0.068 & 0.167 & & \\
\hline Tetracosyl hexadecanoate & $\mathrm{C}_{40} \mathrm{H}_{80} \mathrm{O}_{2}$ & 592 & 0.74 & 1.75 & 0.191 & 0.372 & & \\
\hline Hexacosyl hexadecanoate & $\mathrm{C}_{42} \mathrm{H}_{84} \mathrm{O}_{2}$ & 620 & 0.20 & 0.16 & 0.032 & 0.052 & & \\
\hline Octacosyl hexadecanoate & $\mathrm{C}_{44} \mathrm{H}_{88} \mathrm{O}_{2}$ & 648 & trace & trace & 0.00 & 0.00 & & \\
\hline Total & & & 1.10 & 2.08 & 0.29 & 0.59 & 1.02 & 0.78 \\
\hline
\end{tabular}

$a=\frac{\sum C_{23}+C_{25}+\ldots .+C_{31}}{\sum C_{22}+C_{24}+\ldots .+C_{30}} ; \quad b=\frac{\sum C_{27}+C_{29}+\ldots .+C_{35}}{\sum C_{26}+C_{28}+\ldots .+C_{34}} ; \quad c=\frac{\sum C_{15}+C_{17}+\ldots .+C_{29}}{\sum C_{14}+C_{16}+\ldots .+C_{28}}$.

amyrins, and amyryl acetates, lupeol, and $\alpha$ - and $\beta$ lupeyl acetates. The highest triterpenoid concentrations were observed in the propolis from the Bako (97.6\%) and Gedo (93.7\%) areas, where the major vegetation is dominated by Acacia species, as well as Euphorbiaceae species (Croton macrostachys) and Boraginaceae species (Cordia africana). $\beta$-Amyrin was the major triterpenoid in the samples from the Enemor and Holleta with relative concentrations of $83.8 \%$ and $63.1 \%$, respectively. Whereas, $\alpha$-amyryl acetate was the major compound in the samples from the Bako with a relative concentration of $46.7 \%$, followed by $\beta$-amyryl acetate at $44.9 \%$. In the propolis from the Gedo the major compounds were also $\beta$-amyryl acetate $(53.8 \%)$ followed by $\alpha$-amyryl acetate (29.7\%). Lupeol and $\alpha$ - and $\beta$ - lupeyl acetates were also present in significant amounts (Table 1). This percentage variation in the contents is likely due to different plant species of the same family. As previously mentioned, these triterpenoid compounds were also detected in propolis samples from Brazil and Egypt (El-Hady \& Hegazi 2002; Hegazi \& El-Hady 2002; de Castro Ishida et al. 2011) as well as from Cuba (Márquez Hernández et al. 2010). This indicates that triterpenoid compounds are likely dominant components of propolis samples from tropical and semi-tropical regions.

The presence of triterpenoids (mainly amyrins and amyryl acetates) can act as antibacterial and antitumor agents (Sforcin \& Bankova 2011; de Castro Ishida et al. 2011). Obviously, the main source of triterpenoids in propolis is the surrounding vegetation. Therefore, the determination of the chemical compositions of the regional vegetation should be considered, because it will be useful for investigating the pharmacologically active components of local plants as well as of propolis. 

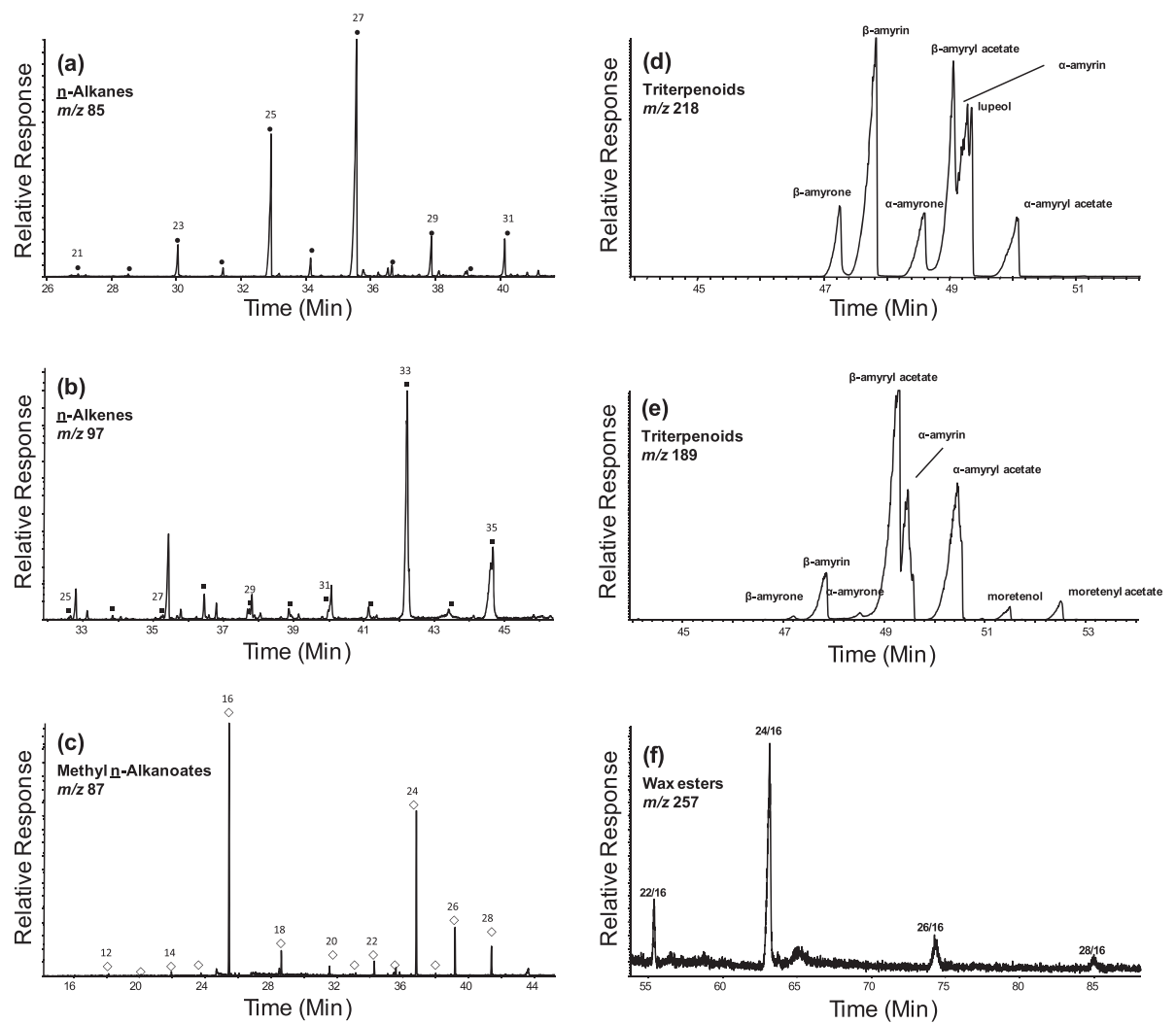

Figure 2 Examples of typical GC-MS key ion plots for (a) n-alkanes, (b) n-alkenes, (c) methyl n-alkanoates, (d) and (e) triterpenoids and (f) wax esters (numbers refer to the carbon number).

\section{$n$-Alkanes and $n$-alkenes}

The relative concentrations of $n$-alkanes in these samples ranged from $0.87 \%$ to $16.9 \%$ of the total extracts with a mean of $5.82 \pm 7.48 \%$ (Table 1 ). The lowest relative concentration $(0.87 \%)$ was measured in the propolis from Bako, while the highest concentration (16.9\%) was in the sample from the Holleta area. The dominant $n$ alkanes were in the range of $C_{21}$ to $C_{31}$, with a carbon number maximum concentration $\left(C_{\max }\right)$ at 27 (e.g. Figure 2a, (Mazurek \& Simoneit 1984)). The carbon preference index (CPI, (Mazurek \& Simoneit 1984)) varied from 10.95 to 13.56 with an average of $12.75 \pm 1.46$ (Table 1). Plant wax $n$-alkanes generally have a $C_{\max }$ in the range of $\mathrm{C}_{25}-\mathrm{C}_{31}$, which varies depending on the plant species as well as the season and locality (e.g. (Eglinton \& Hamilton 1967)). Thus, the odd carbon number preference of the $C_{21}-C_{31} n$-alkanes and the $C_{\max }$ at 27 indicate the major sources of these n-alkanes are likely from the beeswax (Tulloch 1970).

The relative concentrations of the n-alkenes ( $\Delta^{\mathbf{1}}$ or $\Delta^{9}$ ) ranged from $0.85 \%$ to $15.92 \%$ with a mean of $6.23 \pm$ $6.96 \%$. The highest relative concentration (15.92\%) was found in the propolis sample from the Holleta area and the minimum $(0.85 \%)$ in the samples from Bako. The nalkenes ranged from $C_{25}$ to $C_{36}$ with a $C_{\max }$ at 33 . The odd carbon numbered $n$-alkenes were dominant with a CPI of 2.49 to 7.24 (mean $5.30 \pm 2.02$ ). The distribution of $n$-alkenes with major concentrations of the odd numbered homologues and $\mathrm{C}_{\max }$ at 33 supports an origin from insect wax (Jackson 1972; Jackson \& Baker 1970), possibly from alteration of long chain n-alkanols.

\section{Methyl $n$-alkanoates}

The concentrations of methyl $n$-alkanoates were relatively low at $0.19 \%$ to $1.14 \%$ with a mean of $0.64 \pm 0.40 \%$ (Table 1). They ranged from $C_{13}$ to $C_{29}$ with a $C_{\max }$ at 17 and 25 (as acids $C_{\max }=16$ and 24) (Figure 2c). Methyl $n$-alkanoates may be natural or form by transesterification of $n$-alkanoic acids during extraction as indicated by their low relative concentrations. The highest concentration (1.14\%) was found for the propolis sample from Gedo and the lowest $(0.19 \%)$ from Bako. The methyl $n$-alkanoates of these samples have a strong even carbon number predominance as the alkanoic acids (CPI > 17, except for Gedo, Table 1), indicating that they are originally from natural biota (Harwood \& Russell 1984).

\section{Long chain wax esters}

Long chain wax esters were also detected in these samples with relative concentrations of $0.29 \%$ to $2.08 \%$, 
and consisting mainly of docosanyl-, tetracosanyl-, hexacosanyl- and octacosanyl hexadecanoates. The major compound of the wax esters was tetracosanyl hexadecanoate in all samples (Table 1, Figure 2f). They are likely derived from lipid components of terrestrial plants (Baker 1982; Kolattukudy 1976; Hamilton 1995) of the region or from waxes secreted by the bees (Tulloch 1971). Subsequent reports have shown that the components of waxes in some younger plants are generally alcohols (40\%) and they are mainly wax esters (42\%) in older plants (Avato et al. 1990; Bianchi et al. 1989). The vegetation wax ester composition depends not only on plant species, but also on the geographical location (Sforcin \& Bankova 2011). Waxes secreted by bees contain more than $15 \%$ of wax esters (Katzav-Gozansky et al. 1997). Bee wax esters generally include tetradecyl-dodecanoate, tetradecanoate and hexadecanoate, as well as hexadecyltetradecanoate and hexadecanoate (Katzav-Gozansky et al. 1997).

\section{Unique composition}

It has been reported that propolis components, which are complex, have biological properties including antimicrobial, antioxidant and anticancer activities (Lustosa et al. 2008; Naito et al. 2007; Diaz-Carballo et al. 2008). Propolis was also reported to have effects against cariogenic bacteria (de Castro Ishida et al. 2011). Triterpenoids are major and to date unique components of these propolis samples from different regions in Ethiopia, indicating a high potential as sources of biologically active substances. Further studies are needed to investigate the biological activities of these propolis samples, and the correlations between their chemical compositions and botanical origins.

\section{Conclusion}

The solvent-extractable organic matter (DCM:MeOH) of propolis samples from four regions in Ethiopia have been characterized using GC-MS techniques. The mixed solvent was used to extract both polar and non-polar compounds of proplis samples. The major compounds were in order: triterpenoids $>>n$-alkanes $\sim n$-alkenes $>$ long chain wax esters $>$ methyl $n$-alkanoates. The predominant triterpenoids were $\alpha$ - and $\beta$-amyrins, $\alpha$ - and $\beta$-amyryl acetates, followed by lupeol, and $\alpha$ - and $\beta$-lupeyl acetates. $n$-Alkanes and n-alkenes ranged from $C_{21}$ to $C_{31}$ and $C_{25}$ to $C_{35}$ with $C_{\max }$ at 27 and 33, respectively. Long chain wax esters and methyl n-alkanoates were minor components in these samples. The sources of the major triterpenoids are from the regional Acacia waxes and gums. Phenols (e.g. flavonoids) or other antioxidants were not detectable in these samples.

The variation in the identities of propolis components among various reports is likely due to diverse environmental source vegetation, and different extraction methods and solvents used. Therefore, a standardized analytical method should be adopted in order to be able to compare results obtained by different investigators.

\section{Materials and methods \\ Sampling}

The propolis samples were collected from the central parts of Ethiopia representing highlands and midland areas. The specific areas were: Enemor $\left(8^{\circ} 05^{\prime} 44.15^{\prime \prime} \mathrm{N}\right.$; $37^{\circ}$ $52^{\prime} 06.15^{\prime \prime} \mathrm{E}$, at an attitude of $\left.2000 \mathrm{~m}\right)$, Holleta $\left(9^{\circ} 03^{\prime} 26.19^{\prime \prime} \mathrm{N}\right.$, $38^{\circ} 33^{\prime} 22.45^{\prime \prime} \mathrm{E}$, altitude $\left.2370 \mathrm{~m}\right)$, Bako $\left(9^{\circ} 06^{\prime} 59.23^{\prime \prime} \mathrm{N}, 37^{\circ}\right.$ 03'23.02”E, altitude $1670 \mathrm{~m}$ ), and Gedo (9 $00^{\prime} 59.12^{\prime \prime} \mathrm{N}, 37^{\circ}$ 2658.19 ”E, altitude $2515 \mathrm{~m}$ ) (Figure 3 ). The major vegetation of these regions is comprised of different species of

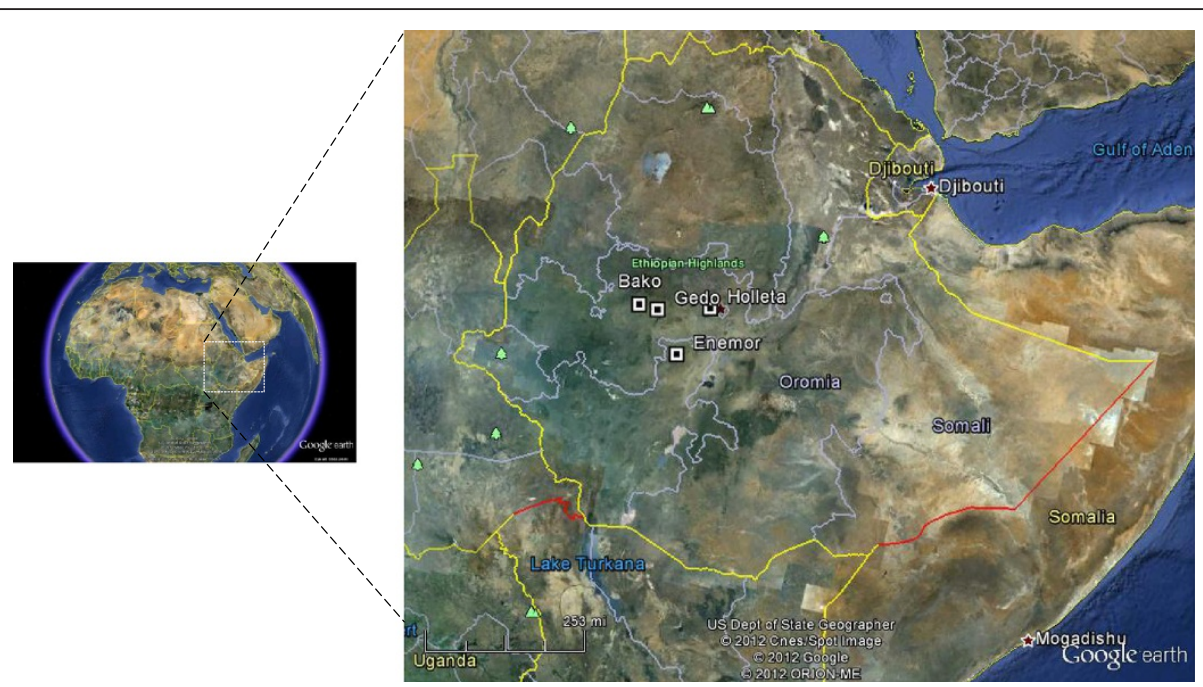

Figure 3 Map showing the locations of the propolis sample collection. 
Acacia, Euphorbiaceae sp. Croton macrostachys, and Boraginaceae sp. Cordia africana. The propolis samples were collected using a stainless steal spatula (>30 g of each) in a Teflon-caped glass container, labeled and kept in a freezer until analysis.

\section{Extraction}

About $20 \mathrm{~g}$ of each sample was broken up and extracted three times using ultrasonic agitation for a $15 \mathrm{~min}$ period each with a mixture of dichloromethane (DCM) and methanol (MeOH, $40 \mathrm{~mL}, 3: 1 \mathrm{v}: \mathrm{v})$ mixture to make certain that both polar and non-polar compounds were extracted. The extraction was carried out in a precleaned beaker. The extract was then filtered using a filtration unit containing an annealed glass fiber filter for the removal of undissolved particles. The filtrate was first concentrated on a rotary evaporator and then reduced using a stream of dry nitrogen gas to a volume of approximately $2 \mathrm{~mL}$. The volume was then adjusted to exactly $2 \mathrm{~mL}$ by addition of DCM:MeOH (3:1, v:v). A $50-\mu \mathrm{L}$ aliquot of each total extract was derivatized with silylating reagent $[\mathrm{N}, \mathrm{O}-\mathrm{bis}($ trimethylsilyl)trifluoroacetamide, BSTFA, Pierce Chemical Co.] by the standard procedure (Knapp 1979), before analysis by gas chromatography-mass spectrometry (GC-MS). This derivatizing agent replaces the $\mathrm{H}$ in hydroxyl groups with a trimethylsilyl $\left[\left(\mathrm{CH}_{3}\right)_{3} \mathrm{Si}\right.$, i.e. TMS $]$ group for better $\mathrm{GC}$ resolution of polar compounds.

\section{Chemical analysis}

Instrumental analysis by GC-MS was carried out with an Agilent 6890 gas chromatograph coupled to a 5973 Mass Selective Detector, using a DB-5MS (Agilent) fused silica capillary column $(30 \mathrm{~m} \times 0.25 \mathrm{~mm}$ i.d., $0.25 \mu \mathrm{m}$ film thickness) and helium as carrier gas. The GC was temperature programmed from $65^{\circ} \mathrm{C}$ (2 min initial time) to $310^{\circ} \mathrm{C}$ at $6^{\circ} \mathrm{C} \mathrm{min}^{-1}$ (isothermal for $55 \mathrm{~min}$ final time) and the MS was operated in the electron impact mode at $70 \mathrm{eV}$ ion source energy. Mass spectrometric data were acquired and processed using the GC-MS ChemStation data system.

\section{Identification and quantification}

The identification of $n$-alkanes was based on the GC-MS data. Retention times were compared with those of external standards. The identities of triterpenoids, $n$-alkanes, $n$-alkenes, $n$-alkanoic acids, methyl $n$-alkanoates, and long chain wax esters are based primarily on their mass spectra (i.e. key ions at $m / z 191 / 189,85,83,117,87$, and 257 , respectively), comparison with those of standards or in the literature, and gas chromatographic retention times. Average response factors were calculated for each compound. All quantifications were based on the compound peak areas derived from the ion fragmentograms correlated with the total ion current (TIC) trace.

\section{Competing interests}

The authors declare that they have no competing interests.

\section{Authors' contributions}

AIR proposed the idea, analyzed the data and wrote the manuscript; NA and NIMB collected the samples and carried out the chemical analyses; AA, BRTS, $\mathrm{AHE}$ and KFA contributed in planning the experimental methods and reviewing and editing the manuscript. All authors read and approved the final manuscript.

\section{Acknowledgements}

This study was supported by the NPST (National Plan for Sciences and Technology) at King Saud University (NPST Grants No. 09-ENV658-02 and No. 11-AGR1748-02)

\section{Author details}

${ }^{1}$ Chair of Green Energy Research, College of Food and Agriculture Sciences, King Saud University, P. O. Box 2460, Riyadh 11451, Saudi Arabia. ${ }^{2}$ College of Earth, Oceanic and Atmospheric Sciences, Oregon State University, Corvallis, Oregon 97331, USA. ${ }^{3}$ Department of Earth and Environmental Sciences, Faculty of Science, Sana'a University, Sana'a, Yemen. "Bee Research Unit, Plant Protection Department, College of Food and Agriculture Sciences, King Saud University, P. O. Box 2460, Riyadh 11451, Saudi Arabia. ${ }^{5}$ Department of Chemistry, Oregon State University, Corvallis, Oregon 97331, USA.

Received: 17 February 2014 Accepted: 8 May 2014

Published: 20 May 2014

\section{References}

Akihisa T, Kojima N, Katoh N, Ichimura Y, Suzuki H, Fukatsu M, Maranz S, Masters E (2010) Triterpene alcohol and fatty composition of sea nuts from seven African countries. J Oleo Sci 59:351-360

Avato P, Bianchi G, Pogna N (1990) Chemosystematics of surface lipids from maize and some related species. Phytochemistry 29:1571-1576

Baker EA (1982) Chemistry and morphology of plant epicuticular waxes. In: Cutler DF, Alvin KL, Price CE (eds) The Plant Cuticle. Academic Press, London

Bakowska-Barczak AM, Schieber A, Kalodziejczyk P (2009) Characterization of Saskatoon berry (Amelanchier alnifolia Nutt.) seed oil. J Agric Food Chem 57:5401-5406

Bankova V (2005) Chemical diversity of propolis and the problem of standardization. J Ethnopharmacol 100:114-117

Bankova V, De Castro S, Marcucci M (2000) Propolis: Recent advances in chemistry and plant origin. Apidologie 31:3-15

Banskota AH, Tezuka Y, Kadota S (2001) Recent progress in pharmacological research of propolis. Phytother Res 15:561-571

Barros MP, Sousa JP, Bastos JK, Andrade SF (2007) Effect of Brazilian green propolis on experimental gastric ulcers in rats. J Ethnopharmacol 110:567-571

Bassani-Silva S, Sforcin JM, Amaral AS, Gaspar LFJ, Rocha NS (2007) Propolis effect in vitro on canine transmissible venereal tumor cells. Revista Portuguesa de Ciencias Veterinarias 102:261-265

Bianchi G, Avato P, Scarpa O, Murelli C, Audisio G, Rossini A (1989) Composition and structure of maize epicuticular wax esters. Phytochemistry 28:165-171

Bufalo MC, Figueiredo AS, Sousa JPB, Candeias JMG, Bastos JK, Sforcin JM (2009) Anti-poliovirus activity of Baccharis dracunculifolia and propolis by cell viability determination and real-time PCR. Appl Microbiol 107:1669-1680

Campo Fernandez M, Cuesta-Rubio O, Rosado Perez A, Montes de Oca Porto R, Marquez Hernandez I, Piccinelli AL, Rastrelli L (2008) GC-MS determination of isoflavonoids in seven red Cuban propolis samples. J Agr Food Chem 56:9927-9932

Castaldo S, Capasso F (2002) Propolis, an old remedy used in modern medicine. Fitoterapia 73:S1-6

Chen YW, Wu SW, Ho KK, Lin SB, Huang CY, Chen CN (2008) Characterization of Taiwanese propolis collected from different locations and seasons. J Sci Food Agric 88:412-419

Cirasino L, Pisati A, Fasani F (1987) Contact dermatitis from propolis. Contact Dermatitis 16:110-111

Cox RE, Yamamoto S, Otto A, Simoneit BRT (2007) Oxygenated di- and tricyclic diterpenoids of southern hemisphere conifers. Biochem Syst Ecol 35:342-362

Cursta-Rubio O, Piccineli AL, Campo Fernandez M, Hernandez IM, Rosado A, Rastrelli L (2007) Chemical characterization of Cuban propolis by HPLC-PDA, HPLC-MS, and NMR: the brown, red, and yellow Cuban varieties of propolis. J Agric Food Chem 55:7502-7509 
Cvek J, Medić-Šarí M, Jasprica I, Zubči S, Vitali D, Mornar A, Vedrina- Dragojevi I, Tomi S (2007) Optimization of an extraction procedure and chemical characterization of Croatian propolis tinctures. Phytochem Anal 18:451-459

Daugsch A, Moraes CS, Fort P, Park YK (2008) Brazilian red propolis - chemical composition and botanical origin. Evid Based Complement Alternat Med 5:435-441

de Castro Ishida VF, Negri G, Salatino A, Bandeira MFCL (2011) A new type of Brazilian propolis: Prenylated benzophenones in propolis from Amazon and effects against cariogenic bacteria. Food Chemistry 125:966-972

Diaz-Carballo D, Malak S, Bardenheuer W, Freistuehler M, Reusch HP (2008) The contribution of plukenetione $A$ to the anti-tumoral activity of Cuban propolis. Bioorg Med Chem 16:9635-9643

Edwards S (1976) Some Wild Flowering Plants of Ethiopia. Addis Ababa University Press, Addis Ababa, Ethiopia

Eglinton G, Hamilton RJ (1967) Leaf epicuticular waxes. Science 156:1322-1335

El-Hady FK, Hegazi AG (2002) Egyptian propolis: 2. Chemical composition, antiviral and antimicrobial activities of East Nile Delta propolis. Z Naturforsch C 57c:386-394

Feng T, Wang R, Cai X, Zheng T, Luo X (2010) Anti-human immunodeficiency virus-1 constituents of the bark of Poncirus trifoliate. Chem Pharm Bull 58:971-975

Ghisalberti EL (1979) Propolis: A review. Bee World 60:59-84

Hamilton RJ (ed) (1995) Waxes: Chemistry, Molecular Biology and Functions. The Oily Press, Dundee, WA

Harwood JL, Russell NJ (1984) Lipids in Plants and Microbes. George Allen and Unwin, London

Hegazi AG, El-Hady FK (2002) Egyptian propolis: 3. Antioxidant, antimicrobial activities and chemical composition of propolis from reclaimed lands. Z Naturforsch C 57c:395-402

Hernández-Vázquez L, Mangas S, Palazón J, Navarro-Ocana A (2010) Valuable medicinal plants and resins: Commercial phytochemicals with bioactive properties. Ind Crop Prod 31:476-480

Jackson LL (1972) Cuticular lipids of insects-IV. Hydrocarbons of the cockroaches Periplaneta japonica and Periplaneta americana compared to other cockroach hydrocarbons. Comp Biochem Physiol A Mol Integr Physiol 41:331-336

Jackson LL, Baker GL (1970) Cuticular lipids of insects. Lipids 5:239-246

Katzav-Gozansky T, Soroker V, Hefetz A (1997) Plasticity of caste-specific Dufour's gland secretion in the honey bee (Apis mellifera L.). Naturwissenschaften 84:238-241

Knapp DR (1979) Handbook of Analytical Derivatization Reactions. John Wiley and Sons, New York

Kolattukudy PE (ed) (1976) Chemistry and Biochemistry of Natural Waxes. Elsevier, Amsterdam

Kumazawa S, Nakamura J, Murase M, Miyagawa M, MR A, Fukumoto S (2008) Plant origin of Okinawan propolis: honeybee behavior observation and phytochemical analysis. Naturwissenschaften 95:781-786

Lotti C, Campo Fernandez M, Piccinelli AL, Cuesta-Rubio O, Marquez Hernandez I, Rastrelli L (2010) Chemical constituents of red Mexican propolis. J Agr Food Chem 58:2209-2213

Lustosa SR, Galindo AB, Nunes LCC, Randau KP, Rolin Neto PJ (2008) Propolis: Updates on chemistry and pharmacology. Brazilian J Pharm 18:447-454

Lutta KP, Bill C, Akenga AT, Cornelius WW (2008) Antimacrobial marine natural products from sponges Axnella infundibuliformis. Nat Prod Rep 25:110-127

Manguro LOA, Opiyo SA, Herdtweck E, Lemmen P (2009) Triterpenes of Commiphora holtziana oleo-gum resin. Can J Chem 87:1173-1179

Marcucci MC (1995) Propolis: chemical composition, biological properties and therapeutic activity. Apidologie 26:83-99

Markham KR, Mitchell KA, Wilkins AL, Daldy JA, Lu Y (1996) HPLC and GC-MS identification of the major organic constituents in New Zealand propolis. Phytochemistry 42:205-211

Márquez Hernández I, Cuesta-Rubio O, Fernández MC, Pérez AR, Porto RMO, Piccinelli AL, Rastrelli L (2010) Studies on the constituents of yellow Cuban propolis: GC-MS determination of triterpenoids and flavonoids. J Agric Food Chem 58:4725-4730

Mazurek MA, Simoneit BRT (1984) Characterization of biogenic and petroleum-derived organic matter in aerosols over remote, rural, and urban areas. In: Keith LH (ed) Identification and analysis of organic pollutants in air. Ann Arbor Science, Woburn, pp 353-370

Melliou E, Chinou I (2004) Chemical analysis and antimicrobial activity of Greek propolis. Planta Medica 70:515-519

Monti M, Berti E, Carminati G, Cusini M (1983) Occupational and cosmetic dermatitis from propolis. Contact Dermatitis 9:163
Moreau RA, Lampi AM, Hicks KB (2009) Fatty acid, phytosterol and polyamine conjugates profiles of edible oils extracted from corn germ, corn fiber, and corn kernels. J Am Oil Chem Soc 86:1209-1214

Naito Y, Yasumuro M, Kondou K, Ohara N (2007) Antiinflammatory effect of topically applied propolis extract in carrageenan-induced rat hind paw edema. Phytother Res 21:452-456

Orsatti CL, Missima F, Pagliarone AC, Bachiega TF, Bufalo MC, Araujo JP Jr, Sforcin JM (2010a) Propolis immunomodulatory action in vivo on Toll-like receptors 2 and 4 expression and on pro-inflammatory cytokines production in mice. Phytother Res 24:1141-1146

Orsatti CL, Missima F, Pagliarone AC, Sforcin JM (2010b) Th1/Th2 cytokines' expression and production by propolis-treated mice. J Ethnopharmacol 129:314-318

Orsi RO, Sforcin JM, Rall VLM, Funari SRC, Barbosa L, Fernandes A Jr (2005) Susceptibility profile of Salmonella against the antibacterial activity of propolis produced in two regions of Brazil. J Venom Anim Toxins 11:109-116

Parolia A, Tomas M, Kundabala M, Mohan M (2010) Propolis and its potential uses in oral health. Int J Med Medical Sci 2:210-215

Popova M, Chinou I, Marekov I, Bankova V (2009) Terpenes with antimicrobial activity from Cretan propolis. Phytochemistry 70:1262-1271

Popova M, Chen CN, Chen PY, Huang CY, Bankova V (2010) A validated spectrophotometric method for quantification of prenylated flavanones in Pacific propolis from Taiwan. Phytochem Anal 21:186-191

Popova M, Trusheva B, Antonova D, Cutajar S, Mifsud D, Farrugia C, Tsvetkova I, Najdenski H, Bankova V (2011) The specific chemical profile of Mediterranean propolis from Malta. Food Chemistry 126:1431-1435

Ramadan M, Ahmad AS, Nafady AM, Mansour Al (2009) Chemical composition of the stem bark and leaves of Ficus pandurata Hance. Nat Prod Res 23:1218-1230

Rosas-Acevedo H, Terrazas T, González-Trujano ME, Guzmán Y, Soto-Hernández M (2011) Anti-ulcer activity of Cyrtocarpa procera analogous to that of Amphipterygium adstringens, both assayed on the experimental gastric injury in rats. J Ethnopharmacol 134:67-73

Salatino A, Teixeira EW, Negri G, Message D (2005) Origin and chemical variation of Brazilian propolis. Evid base Compl Alternative Med 2:33-38

Sforcin JM (2007) Propolis and the immune system: a review. J Ethnopharmacol 113:1-14

Sforcin JM, Bankova V (2011) Propolis: Is there a potential for the development of drugs? J Ethnopharmacol 133:253-260

Silva AM, Simeoni LA, Silveira D (2009) Genus Pouteria: Chemistry and biological activity. Brazilian J Pharm 19:501-509

Simone-Finstrom M, Spivak M (2010) Propolis and bee health: the natural history and significance of resin use by honey bees. Apidologie 41:295-311

Sob SVT, Wabo HK, Tchinda AT, Tane P, Ngadjui BT, Ye Y (2010) Anthraquinones, sterols, triterpenoids and xanthones from Cassia obtusifolia. Biochem Syst Ecol 38:342-345

Trusheva B, Popova M, Bankova V, Tsvetkova I, Naydensky C, Sabatini AG (2003) A new type of European propolis, containing bioactive labdanes. Rivista Italiana EPPOS 36:3-7

Tulloch AP (1970) The composition of beeswax and other waxes secreted by insects. Lipids 5:247-258

Tulloch AP (1971) Beeswax: Structure of the esters and their component acids and diols. Chem Phys Lipids 6:235-265

Ugur A, Sarac N, Duru ME (2011) Chemical composition of antimicrobial activity of endemic Onopordum caricum. Middle East J Sci Res 8:594-598

van Maarseveen C, Jetter R (2009) Composition of the epicuticular and intracuticular wax layers on Kalanchoe daigremontiana (Hamet et Perr. de la Bathie) leaves. Phytochemistry 70:899-906

Vouffo B, Dongo E, Facey P, Thorn A, Sheldrick G, Maier A, Fiebig H, Laatsch H (2010) Antiarol cinnamate and africanoside, a cinnamoyl triterpene and a hydroperoxy-cardenolide from the stem bark of Antiaris africana. Planta Medica 76:1717-1723

Wang F, Li Z, Cui H, Hua H, Jing Y, Liang M (2011) Two new triterpenoids from the resin of Boswellia carterii. J Asian Nat Prod Res 13:193-197

Wesolowska A, Jadczak D, Grzeszczuk M (2011) GC-MS analysis of lemon catnip (Nepeta cataria L. var. citriodora Balbis) essential oil. Acta Chromatographica 23:169-180

Zamami Y, Takatori S, Koyama T, Goda M, Iwatani Y, Doi S, Kawasaki H (2007) Effect of propolis on insulin resistance in fructose-drinking rats. Yakugaku Zasshi 127:2065-2073

doi:10.1186/2193-1801-3-253

Cite this article as: Rushdi et al:: Characteristics and chemical

compositions of propolis from Ethiopia. SpringerPlus 2014 3:253. 